\title{
A New Reagent for Spectrophotometric Determination of Ir(IV): 5-[2-(4-Hydroxyphenyl) hydrazineylidene]- 4-iminothiazolidin-2-one (HPIT)
}

\author{
Oleksandr Tymoshuk, ${ }^{1}$ Lesia Oleksiv, ${ }^{1, \star}$ Orest Fedyshyn, ${ }^{1}$ Petro Rydchuk, ${ }^{1}$ \\ Vasyl Matiychuk ${ }^{1}$ and Taras Chaban ${ }^{2}$ \\ ${ }^{1}$ Department of Chemistry, Ivan Franko National University of Lviv, Kyryla and Mefodiya Str., 6, 79005 Lviv, Ukraine; \\ ${ }^{2}$ Faculty of Pharmacy, Danylo Halytsky Lviv National Medical University, Pekarska Str., 69, 79010 Lviv, Ukraine \\ *Corresponding author: E-mail: l_lozynska@ukr.net
}

Received: 06-15-2020

\begin{abstract}
The paper presents a new azolidone derivative - 5-[2-(4-hydroxyphenyl)hydrazineylidene]-4-iminothiazolidin-2-one (HPIT) studies and its interaction results with iridium(IV) ions. The $\operatorname{Ir}(\mathrm{IV})$ with this reagent in the $\mathrm{pH}=5.0$ without heating forms a stable complex $\left(\lambda_{\max }=328 \mathrm{~nm}\right)$. The stoichiometric ratio of $\operatorname{Ir}(\mathrm{IV})$ to the reagent in complex is 1:1. The molar absorptivity and Sandell's sensitivity are $5.57 \times 10^{3} \mathrm{~L} \mathrm{~mol}^{-1} \mathrm{~cm}^{-1}$ and $0.034 \mu \mathrm{g} \mathrm{cm}^{-2}$ respectively. The calibration curve is linear in the range of $1.0-11.5 \mu \mathrm{g} \mathrm{mL}-1$ of $\operatorname{Ir}(\mathrm{IV})(\mathrm{R}=0.9996)$. The limit of detection is $0.4 \mu \mathrm{g} \mathrm{mL} \mathrm{m}^{-1}$. Based on the conducted investigation a rapid and simple, spectrophotometric method for the determination of $\operatorname{Ir}(\mathrm{IV})$ using 5-[2-(4-hydroxyphenyl)hydrazineylidene]-4-iminothiazolidin-2-one as a chromophoric reagent was developed. The iridium(IV) was determined in various synthetic mixtures and alloys.
\end{abstract}

Keywords: Iridium(IV); spectrophotometry; 5-[2-(4-hydroxyphenyl)hydrazineylidene]-4-iminothiazolidin-2-one; azolidones.

\section{Introduction}

The relevance of platinum metals and their compounds usage encourages the development of simple, rapid, inexpensive, selective, and sensitive methods for the determination of trace amounts of these metals in complex samples. Spectrophotometric methods of analysis are successfully used to solve this problem in analytical chemistry with the use of organic reagents containing functionalanalytical groups. ${ }^{1,2}$

Spectrophotometric methods are one of the most widely used physical-chemical analysis methods in industrial and research laboratories. The main advantages of spectrophotometry are versatility, sufficient sensitivity to solve specific analytical problems, simplicity, the possibility of analysis automation, which provides it a leading place in the modern analytical chemistry. Spectrophotometric methods of platinoids determination are characterized by different sensitivity $\left(\varepsilon_{\lambda} \sim 10^{3}-10^{5} \mathrm{~L} \mathrm{~mol}^{-1} \mathrm{~cm}^{-1}\right)$ depending on the choice of reagent. Their sensitivity is significantly increased using organic reagents, namely heterocyclic azo derivatives and sulfur-containing compounds. ${ }^{1-3}$ Among a large number of azo dyes, azolidones and their derivatives are of particular interest. The color reactions of noble metals with this group of reagents are highly sensitive $\left(\varepsilon=(0.4-1.5) \times 10^{4} \mathrm{~L} \mathrm{~mol}^{-1} \mathrm{~cm}^{-1}\right)$ and contrast $(\Delta \lambda=70$ $80 \mathrm{~nm}$ ). Azorodanines contain several functional-analytical groups in their molecules, which makes it possible to use them as group reagents for the precious metals determination..$^{3-6}$

Our scientific group first investigated the analytical properties of several azolidone derivatives and successfully used them to determine the number of ions: $\mathrm{Cu}(\mathrm{II}), \mathrm{Ni}(\mathrm{II})$, Cd(II), Zn(II), Hg(II), Pd(II), Pt(IV), Rh(III), Ir(IV), $\mathrm{Ru}(\mathrm{IV}) .^{7-21}$

Due to the wide usage of iridium in various industries (such as jewelry, electrical equipment, dental alloys, automobile, chemical, and electronics industries, the field of photography and aviation), it is important to develop efficient analytical methods for this metal determination in various samples. ${ }^{22,23}$ Most of spectrophotometric methods for the Iridium determination are not enough sensi- 
tive, selective and need heating or extraction. ${ }^{1,2,4,11,24-27}$ For this reasons the goal of our research was to find the effective analytical reagents for spectrophotometric $\operatorname{Ir}(\mathrm{IV})$ determination using azolidones derivatives. One of them was a new reagent - 5-[2-(4-hydroxyphenyl)hydrazineylidene]-4-iminothiazolidin-2-one (HPIT).

\section{Experimental}

\section{1. Equipment}

Spectrophotometric measurements were performed with a computerized spectrophotometer, model ULAB 108-UV, fitted with $1.0 \mathrm{~cm}$ quartz cells.

Computerized device MTech OVA-410 with a linear potential sweep was used for voltammetric measurements. ${ }^{28}$ A three-electrode system including dropping mercury electrode (working electrode), a saturated calomel electrode (reference electrode), and platinum (counter electrode) were used.

The $\mathrm{pH}-150 \mathrm{M}$ pH-meter equipped with a combined glass electrode was used to measure the $\mathrm{pH}$ values of solutions.

${ }^{1} \mathrm{H}$ NMR spectra were registered on the spectrometer Varian Mercury UX-400, DMSO- $\mathrm{d}_{6}$ was used as a solvent, tetramethylsilane as a standard.

\section{2. Reagents}

The stock solution of iridium(IV) chloride was prepared by melting the exact mass of pure iridium $(99.99 \%)$ with the oxidizing mixture of $\mathrm{NaNO}_{3}+\mathrm{NaOH}(1: 3, v / v)$, and $\mathrm{BaO}_{2}$ at $950 \mathrm{~K}$ for $45-60 \mathrm{~min}$. Then the fusion was dissolved in $3.0 \mathrm{~mol} \mathrm{~L} \mathrm{~m}^{-1}$ hydrochloric acid. The existence form of $\operatorname{Ir}(\mathrm{IV})\left(\left[\mathrm{IrCl}_{6}\right]^{2-}\right)$ in the obtained solution was confirmed by comparing its absorption spectra with the transferred data. ${ }^{29}$ The obtained solution of $\operatorname{Ir}(\mathrm{IV})$ was additionally standardized using the titration method - iodometry, due to possible losses during sintering. ${ }^{1,2}$ Standard transferred solutions of $\operatorname{Ir}(\mathrm{IV})$ were prepared by diluting an aliquot of $\mathrm{Ir}(\mathrm{IV})$ initial stock solution in $1.0 \mathrm{~mol} \mathrm{~L}^{-1} \mathrm{HCl}$.

The solution of 5-[2-(4-hydroxyphenyl)hydrazineylidene]-4-iminothiazolidin-2-one was prepared by dissolving the exact mass of the pre-purified reagent in dimethyl sulfoxide. Working solutions of HPIT were prepared by diluting an aliquot of the stock solution in dimethyl sulfoxide. The 5-[2-(4-hydroxyphenyl)hydrazineylidene]-4-iminothiazolidin-2-one was synthesized by the following procedure: $0.01 \mathrm{~mol}$ of 4 -aminophenol was dissolved in $3 \mathrm{ml}$ of concentrated hydrochloric acid, after which $5 \mathrm{ml}$ of water was added. The solution obtained at this stage, with cooling, was diazotized with $0.72 \mathrm{~g}$ of transferred nitrite dissolved in $3 \mathrm{~mL}$ of water. The resulting diazonium salt was added over 30 minutes to a solution of $0.01 \mathrm{~mol}$ of 4 -iminothiazolidin-2-one previously dissolved in $80 \mathrm{ml}$ of glacial acetate acid containing $4 \mathrm{~g}$ of anhydrous sodium acetate $(\mathrm{pH}=4.5-5.0)$ with stirring and was cooled. The mixture was left at $12 \mathrm{~h}$, after which it was poured into $200 \mathrm{~mL}$ of water. The precipitate was filtered, washed on the filter with water, dried, and recrystallized. ${ }^{1} \mathrm{H} \mathrm{NMR}\left(400 \mathrm{MHz}, \mathrm{DMSO}-\mathrm{d}_{6} ; \delta, \mathrm{ppm}\right): 6.70(\mathrm{~d}, J=9.0 \mathrm{~Hz}$, $\left.2 \mathrm{H}, \mathrm{C}_{6} \mathrm{H}_{4}\right), 7.28\left(\mathrm{~d}, J=9.0 \mathrm{~Hz}, 2 \mathrm{H}, \mathrm{C}_{6} \mathrm{H}_{4}\right), 8.71(\mathrm{~s}, 1 \mathrm{H}, \mathrm{NH})$, 8.97 (s, 1H, NH), 10.17 (s, 1H, NH). The purity of HPIT was determined by chromatography-mass spectrometry.

The solution of $\mathrm{HCl}$ was prepared by dilution of concentrated $\mathrm{HCl}$. The solutions of sodium salts (to study the effect of anions), $\mathrm{NaCl}$ and $\mathrm{NaOH}$ were prepared by dissolving an appropriate amount of respective salts and $\mathrm{NaOH}$ in distilled water. The Britton-Robinson buffer (BRB) was prepared by mixing solutions of boric, phosphoric and acetic acids. ${ }^{30}$ The solutions of various metals (to study the effect of cations) were prepared by dissolving the exact mass of the corresponding metal in $\mathrm{HCl}$ or $\mathrm{HNO}_{3}$ acids either its mixture, or their salts in distilled water or dilute hydrochloric or nitric acids. The solutions of Rh(III) and $\mathrm{Ru}(\mathrm{IV})$ were prepared by sintering corresponding metal with the oxidizing mixture $\mathrm{NaNO}_{3}+\mathrm{NaOH}(1: 3$, $v / v$ ) with further dissolving the fusion in $3.0 \mathrm{~mol} \cdot \mathrm{L}^{-1} \mathrm{HCl}$.

All chemicals used were of analytical grade and distilled water was used for the preparation of the aqueous solution.

\subsection{Procedure}

\section{Research of the HPIT spectral characteristics}

Aliquots of $2.0 \mathrm{~mL}$ HPIT working solution $(2.5 \times$ $\left.10^{-4} \mathrm{~mol} \mathrm{~L}^{-1}\right)$ were transferred into a series of $25.0 \mathrm{~mL}$ transferred flasks, then $2.0 \mathrm{~mL} \mathrm{BRB}\left(1.5 \mathrm{~mol} \mathrm{~L}^{-1}\right), 1.25 \mathrm{~mL}$ $\mathrm{NaCl}\left(2.0 \mathrm{~mol} \mathrm{~L}^{-1}\right)$ and water $(\sim 15-20 \mathrm{~mL})$ were added to each flask. The $\mathrm{pH}$ values $(2.0-12.0)$ were adjusted using $\mathrm{NaOH}\left(4.0 \mathrm{~mol} \mathrm{~L}^{-1}\right)$ and then diluted to volume with distilled water. The solution with $\mathrm{pH}=1.0$ was prepared as described above but without $\mathrm{BRB}$ addition and $\mathrm{pH}$ value was adjusted using $\mathrm{HCl}\left(6.0 \mathrm{~mol} \mathrm{~L}^{-1}\right)$. The absorption spectra were measured against distilled water as blank.

General procedure for the determination of $\operatorname{Ir}(I V)$ with HPIT An aliquot of $\operatorname{Ir}(\mathrm{IV})$ solution (in the range of 1.0$11.5 \mu \mathrm{g} \mathrm{mL}^{-1}$ in the final volume $), 2.5 \mathrm{~mL}(1.0 \times$ $\left.10^{-3} \mathrm{~mol} \mathrm{~L}^{-1}\right)$ HPIT, $1.0 \mathrm{~mL}\left(1.5 \mathrm{~mol} \mathrm{~L}^{-1}\right) \mathrm{BRB}$ and $1.25 \mathrm{~mL}$ $\left(2.0 \mathrm{~mol} \mathrm{~L}^{-1}\right) \mathrm{NaCl}$ were placed into $25.0 \mathrm{~mL}$ calibrated flasks and then distilled water was added $(\sim 15 \mathrm{~mL})$. The $\mathrm{pH}$ was adjusted to $\sim 5.0$ with $\mathrm{NaOH}$ solution and diluted to the mark with distilled water. The absorbance was measured at $328 \mathrm{~nm}$ against a reagent blank.

\section{Determination the stoichiometric ratio of the $\operatorname{Ir}(I V)-H P I T$ complex}

The equimolar solutions of $\operatorname{Ir}(\mathrm{IV})$ and HPIT $(1.0 \times$ $10^{-3} \mathrm{~mol} \mathrm{~L}^{-1}$ ) were used to determine the metal to ligand ratio by Job's method of continuous variation. The total concentration $\mathrm{C}_{\mathrm{Ir}(\mathrm{IV})}+\mathrm{C}_{\mathrm{HPIT}}$ was equal $1.0 \times 10^{-4} \mathrm{~mol} \mathrm{~L}^{-1}$ 
in a $25.0 \mathrm{~mL}$ volumetric flask. Then $1.0 \mathrm{~mL}\left(1.5 \mathrm{~mol} \mathrm{~L}^{-1}\right)$ BRB, $1.25 \mathrm{~mL}\left(2.0 \mathrm{~mol} \mathrm{~L}^{-1}\right) \mathrm{NaCl}$, and distilled water $(\sim 15$ $\mathrm{mL}$ ) were added. The $\mathrm{pH}$ was adjusted to 5.0 by $\mathrm{NaOH}$ and diluted with distilled water to the calibration mark. The absorbance values were recorded at $328 \mathrm{~nm}$.

The mole-ratio method was performed in the transferred way: into a series of $25.0 \mathrm{~mL}$ volumetric flasks the $\operatorname{Ir}(\mathrm{IV})$ solution with fixed concentration $\left(0.5 \mathrm{~mL}\right.$ of $1.0 \times 10^{-3}$ mol L$\left.)^{-1}\right)$, an aliquot $0.10-10.0 \mathrm{~mL}\left(5.0 \times 10^{-4} \mathrm{~mol} \mathrm{~L}^{-1}\right)$ HPIT, $1.0 \mathrm{~mL}\left(1.5 \mathrm{~mol} \mathrm{~L}^{-1}\right) \mathrm{BRB}, 1.25 \mathrm{~mL}\left(2.0 \mathrm{~mol} \mathrm{~L}^{-1}\right) \mathrm{NaCl}$, and distilled water $\sim 20 \mathrm{~mL}$ were added. The $\mathrm{pH}$ was adjusted to $\mathrm{pH}=5.0$ by adding $\mathrm{NaOH}$ and diluted up to the mark with water. Then, the absorbance at $328 \mathrm{~nm}$ was measured.

\section{Alloys samples preparation}

The alloys $\left(\mathrm{Gd}_{2} \mathrm{Ir}_{3} \mathrm{Al}_{9}, \mathrm{~Tb}_{2} \mathrm{Ir}_{3} \mathrm{Al}_{9}\right)$ were synthesized by arc melting of pure metals ( $\mathrm{Gd} \geq 99.86 \%, \mathrm{~Tb} \geq 99.83 \%$, Ir $\geq 99.9 \%, \mathrm{Al} \geq 99.998 \%$ ) under an argon atmosphere and heated to $873 \mathrm{~K}$, held at that temperature for $720 \mathrm{~h}$ and then cooled to room temperature. ${ }^{31}$

The solutions of alloys samples were prepared by dissolving of $0.05-0.1 \mathrm{~g}$ of sample in $10-20 \mathrm{~mL}$ of $\mathrm{HCl}$ and $\mathrm{HNO}_{3}(10: 1, v / v)$ mixture and heating for $\sim 2 \mathrm{~h}$. Then the black residue was filtered and filtrate transferred to a $200.0 \mathrm{~mL}$ volumetric flask. The residue was sintered with a $\mathrm{NaNO}_{3}$ and $\mathrm{NaOH}(1: 3, v / v)$ mixture at $950 \mathrm{~K}(60 \mathrm{~min})$. The melt was dissolved in $3.0 \mathrm{~mol} \mathrm{~L}^{-1} \mathrm{HCl}$. The obtained solution was transferred to the previous filtrate and distilled water was added to the mark. The $0.4-1.5 \mathrm{~mL}$ of alloys aliquots were taken for $\operatorname{Ir}(\mathrm{IV})$ determination with HPIT as described above. ${ }^{11}$

\section{Results and Discussion}

\section{1. Research Spectral Characteristics of the HPIT}

We researched a new reagent - 5-[2-(4-hydroxyphenyl)hydrazineylidene]-4-iminothiazolidin-2-one, which is a derivative of azolidone (Fig. 1). HPIT is the crystalline yellow powder poorly soluble in water and ethanol but well soluble in dimethylformamide and dimethyl sulfoxide. The melting point is $515 \mathrm{~K}$.

In our previous work, ${ }^{32}$ we investigated the effect of the medium acidity on the absorption spectra of HPIT over the $\mathrm{pH}$ range 1.0-12.0. As shown by the results of the experiment, the HPIT absorption maximum depends on the $\mathrm{pH}$ of the solution, which is associated with different existence forms depending on the medium acidity (Fig. 2). At $\mathrm{pH}=1.0$, the absorption spectrum is characterized by a maximum at a wavelength of $418 \mathrm{~nm}$, which corresponds to the protonated form of the reagent; at $\mathrm{pH} 2.0-10.0$, the maximum of absorbance shifts slightly to the region of smaller wavelengths $(400 \mathrm{~nm})$, and in the alkaline medium $(\mathrm{pH}>10.0)$ (Fig. 3), there is a course of hydrolysis reaction with the release of ammonia (Scheme 1). The molar absorptivity at $\lambda=418 \mathrm{~nm}$ is $2.04 \times 10^{4} \mathrm{~L} \mathrm{~mol}^{-1} \mathrm{~cm}^{-1}$ $(\mathrm{pH}=1.0)$; at $\lambda=400 \mathrm{~nm}$ is $(1.14-1.85) \times 10^{4} \mathrm{~L} \mathrm{~mol}^{-1} \mathrm{~cm}^{-1}$ $(\mathrm{pH} 2.0-9.0)$ and $1.02 \times 10^{3} \mathrm{~L} \mathrm{~mol}^{-1} \mathrm{~cm}^{-1}(\mathrm{pH}=10.0)$.

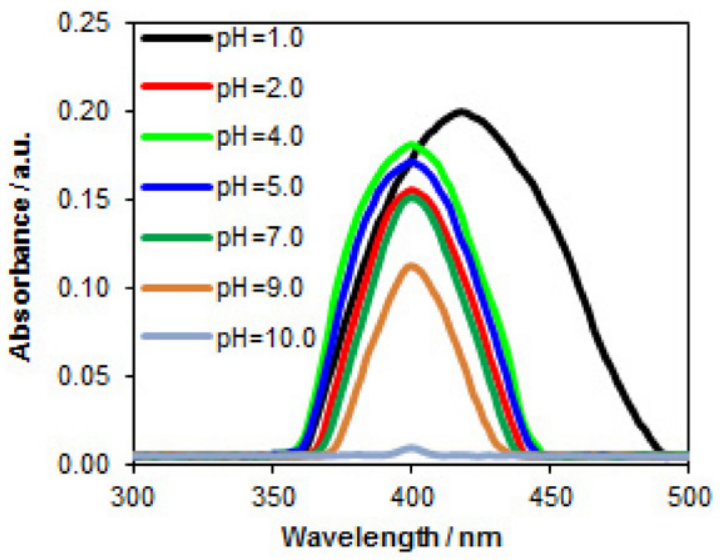

Fig. 2. Absorbance spectra of HPT at different $\mathrm{pH}$

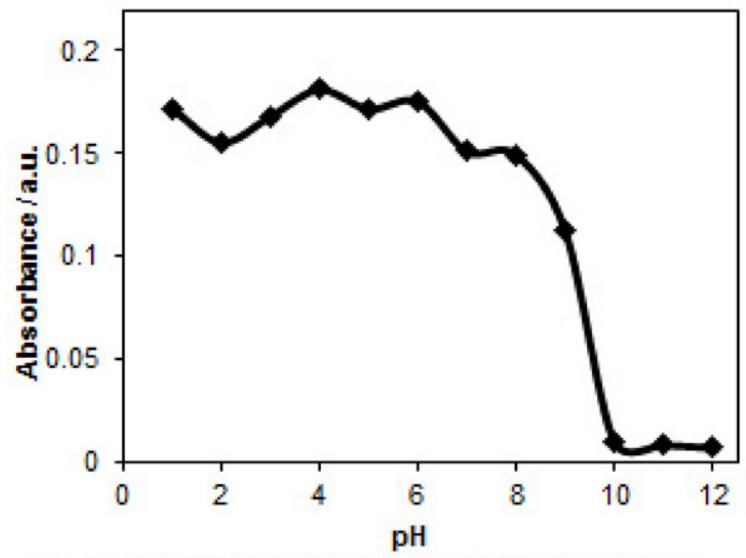

Fig. 3. Effect $\mathrm{pH}$ on the absorbance of HPIT at $400 \mathrm{~nm}$

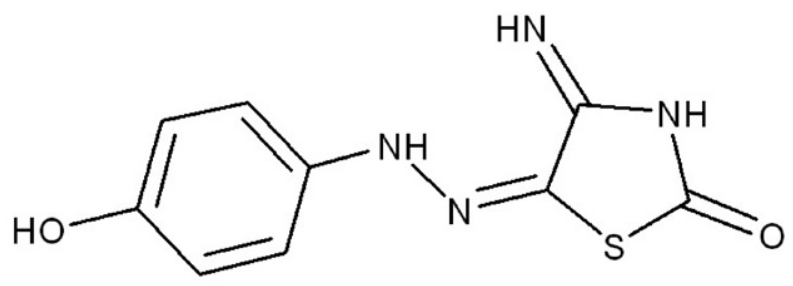

Fig. 1. Structual formula of the HPIT 
<smiles>N=C1NC(=O)S/C1=N\Nc1ccc(O)cc1</smiles>

Scheme 1. Hydrolysis of 5-[2-(4-hydroxyphenyl)hydrazineylidene]-4-iminothiazolidin-2-one

HPIT does not polymerize and does not form tautomeric forms at $\mathrm{pH}=1.0$ in the concentration range of 5.0 $\times 10^{-6}-8.0 \times 10^{-5} \mathrm{~mol} \mathrm{~L}^{-1}$, since in this range the Beer's law is applicable and only one maximum is observed.

\section{2. Investigation of the Interaction of $\operatorname{Ir}(I V)$ with HPIT}

It was found that the $\operatorname{Ir}(\mathrm{IV})$ ions form a complex with HPIT (Fig. 4). The absorption spectra of HPIT, Ir(IV), and $\operatorname{Ir}(\mathrm{IV})$-HPIT were recorded over the range 200 to $550 \mathrm{~nm}$. As shown on Fig. 4 the maximum of the reagent at $400 \mathrm{~nm}(\mathrm{pH}=5.0)$ is reduced in the presence of iridium(IV) ions. Instead, there was an increase in the absorption of $\operatorname{Ir}(\mathrm{IV})$-HPIT in the wavelength range from 250 to $360 \mathrm{~nm}$ compared to the absorption of the reagent, which indicates the interaction. The largest difference in absorption of the reagent and compound is at $\lambda=328 \mathrm{~nm}$.

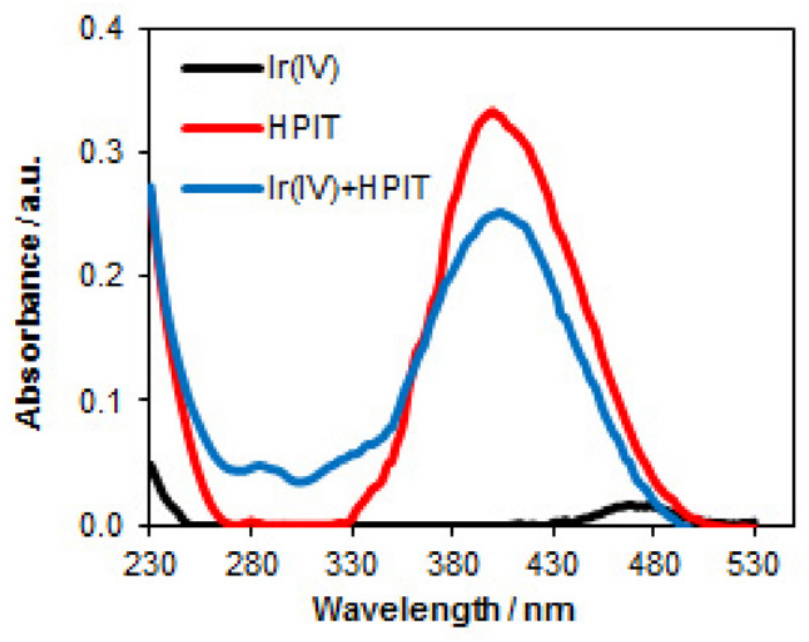

Fig. 4. Absorbance spectra of $\operatorname{Ir}(\mathrm{IV})$, reagent and complex $\operatorname{Ir}(\mathrm{IV})$ with HPIT $\left(\mathrm{pH}=5.0, \mathrm{C}_{\mathrm{ir}(\mathrm{IV})}=8.0 \times 10^{-6} \mathrm{~mol} \mathrm{~L}^{-1}, \mathrm{C}_{\mathrm{HPIT}}=2.0 \times 10^{-5}\right.$ mol L-1)

The effect of various parameters on the formed products absorption intensity was studied and the reaction conditions were optimized.

\section{Effect of $p H$}

The acidity of the medium is one of the important parameters that affect the complexation. Within the $\mathrm{pH}$

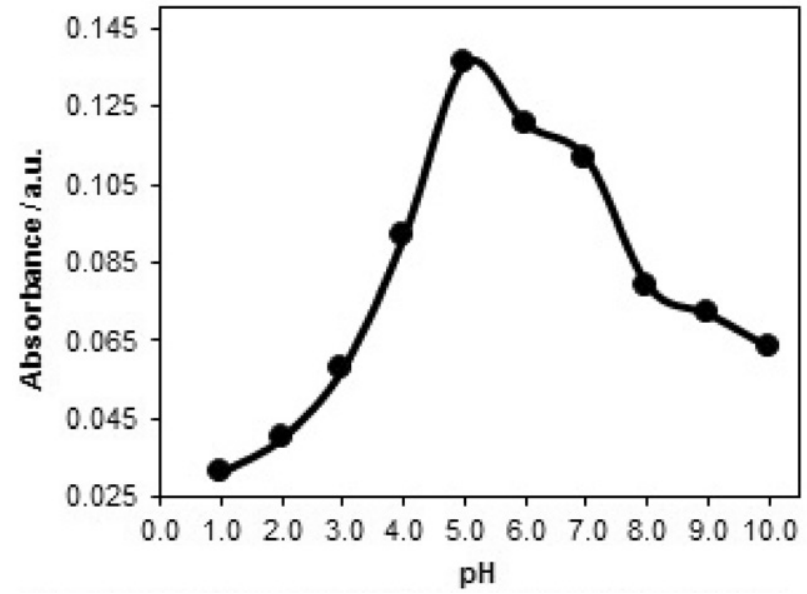

Fig. 5. Effect of $\mathrm{pH}$ on the maximum yield of Ir(IV) with HPIT complex $\left(\lambda=328 \mathrm{~nm}, \mathrm{C}_{\mathrm{ir}(\mathrm{IV})}=2 \times 10^{-5} \mathrm{~mol} \mathrm{~L}^{-1}, \mathrm{C}_{\mathrm{HPIT}}=4 \times 10^{-5}\right.$ $\mathrm{mol} \mathrm{L}-1)$

range from 2.0 to $10.0 \operatorname{Ir}(\mathrm{IV})$ ions form a complex with HPIT (Fig. 5). The maximum yield of complex is at $\mathrm{pH}=5.0$. Hence this value of $\mathrm{pH}$ was selected for further studies.

\section{Effect of time and temperature}

The process of iridium(IV) ions complexation with HPIT occured at room temperature ( 291-296 K) immediately after the acidity of the medium was established. The effect of heating time on the maximum yield of the colored compound was investigated. The solutions heating in a boiling water bath $(\sim 371 \mathrm{~K})$ caused a decrease in the absorption of the solutions, but the complex compound Ir(IV)-HPIT was not destroyed even when heated for $60 \mathrm{~min}$. Therefore it is recommended that the reaction should be carried out at room temperature. The absorbance of obtained Ir(IV)-HPIT complex was stable up to $72 \mathrm{~h}$.

\section{The stoichiometric ratio of complex}

The Job's method of continuous variations (Fig. 6) and the mole-ratio method were used to determine the stoichiometric ratio of the complex. These methods indicate that complex with stoichiometry 1:1 was formed. A 1.5 fold excess of reagent is required for full complexation. The formal stability constant of the $\operatorname{Ir}(\mathrm{IV})$-HPIT complex was calculated and it is equal to $8.9 \times 10^{5}$. 


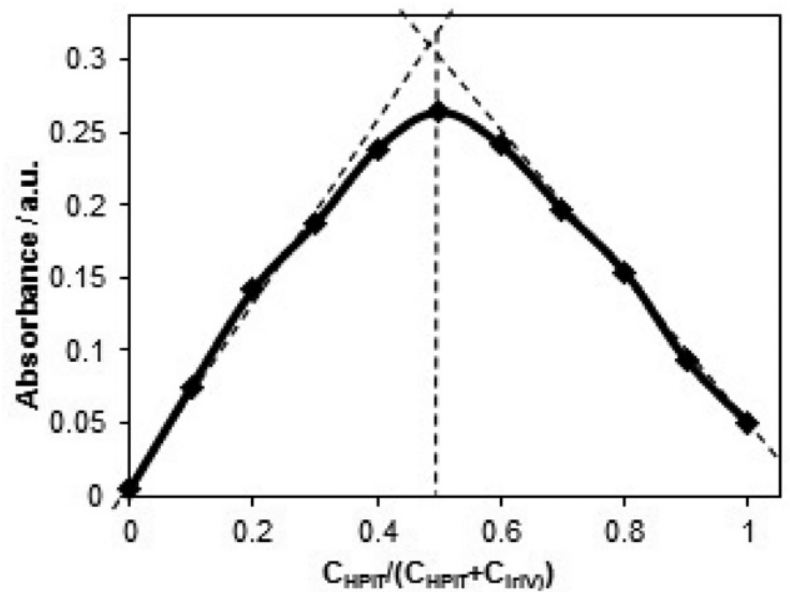

Fig. 6. The method of continuous variations

\section{Calibration curve}

The calibration graph for $\operatorname{Ir}(\mathrm{IV})$ determination with HPIT was constructed using the optimal conditions $\left(\mathrm{pH}=5.0, \lambda=328 \mathrm{~nm}, \mathrm{C}_{\mathrm{HPIT}}=1.0 \times 10^{-4} \mathrm{~mol} \mathrm{~L}^{-1}\right.$, $\left.\mathrm{C}_{\mathrm{NaCl}}=0.1 \mathrm{~mol} \mathrm{~L}^{-1}, \mathrm{C}_{\mathrm{BRB}}=0.06 \mathrm{~mol} \mathrm{~L}^{-1}\right)$ and showed that the system obeys Beer's law in the concentration range of $1.0-11.5 \mu \mathrm{g} \mathrm{mL}^{-1}$ of $\operatorname{Ir}(\mathrm{IV})$. The linear equation is $\Delta \mathrm{A}=(0$ $, 011 \pm 0.004)+(0,0292 \pm 0.0007) \times \mathrm{C}_{\mathrm{Ir}(\mathrm{IV})}(\Delta \mathrm{A}-$ absorbance,

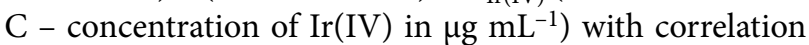
coefficient equal $0.9996, \mathrm{~N}=6, \mathrm{SD}=2.37 \times 10^{-3}$. The molar absorptivities and Sandell sensitivity are $5.57 \times 10^{3}$ $\mathrm{L} \mathrm{mol}{ }^{-1} \mathrm{~cm}^{-1}$ and $0.034 \mu \mathrm{g} \mathrm{cm}^{-2}$ respectively. The limit of detection is $0.4 \mu \mathrm{g} \mathrm{mL}^{-1}$.

\section{3. Selectivity of the $\operatorname{Ir}(I V)$ Determination}

The various cations and anions influence on the iridium(IV) determination were studied under the conditions of the standard procedure. The tolerance limits of tested interfering ions were calculated as the maximum concentrations that do not cause an error of more than $\pm 5 \%$ in an absorbance value. The tolerance limits for foreign ions are shown in Table 1. It has been found that the majority of cations do not interfere significantly. The iridium(IV) ions can be easily determined in the presence of $\mathrm{Tb}(\mathrm{III}), \mathrm{Gd}(\mathrm{II}), \mathrm{Cd}(\mathrm{II}), \mathrm{Zn}(\mathrm{II})$, $\mathrm{Mn}(\mathrm{II}), \mathrm{Ni}(\mathrm{II}), \mathrm{Cu}(\mathrm{II}), \mathrm{Ca}(\mathrm{II}), \mathrm{Mg}(\mathrm{II}), \mathrm{Ba}(\mathrm{II})$ and the studied anions. However, several ions such as Pd(II), Rh(III), Pt(IV), $\mathrm{Ru}(\mathrm{IV})$ interfere seriously. Their effect can be eliminated by using some of the studied anions as masking agents. For example, $\mathrm{Pd}(\mathrm{II})$ and $\mathrm{Ru}(\mathrm{IV})$ were masked using EDTA (the tolerance limits reach 1 for $\mathrm{Pd}(\mathrm{II})$ and 2 for $\mathrm{Ru}(\mathrm{IV})$ ). This method has higher selectivity than most of the spectrophotometric methods of Iridium determination. 1, 2, 4, 11, 24-27

\section{4. Analytical Application}

The developed spectrophotometric method was applied to the determination of $\operatorname{Ir}(\mathrm{IV})$ in synthetic mixtures and alloys to validate it.

\section{Analysis of Ir(IV) in synthetic mixtures}

Different synthetic mixtures were prepared and analyzed using the proposed developed method in order to research the precision and accuracy (Table 2). As can be seen in Table 2, the obtained results are consistent with the

Table 1. Selectivity of $\operatorname{Ir}(\mathrm{IV})$ spectrophotometric determination $\left(\mathrm{C}_{\mathrm{Ir}(\mathrm{IV})}=2.5 \times 10^{-5} \mathrm{~mol} \mathrm{~L}^{-1} ; \mathrm{C}_{\mathrm{HPIT}}=1.0 \times 10^{-4} \mathrm{~mol} \mathrm{~L}^{-1}\right.$; $\left.\mathrm{C}_{\mathrm{NaCl}}=0.1 \mathrm{~mol} \mathrm{~L}^{-1} ; \mathrm{C}_{\mathrm{BRB}}=0.06 \mathrm{~mol} \mathrm{~L}{ }^{-1} ; \mathrm{pH}=5.0 ; \lambda=328 \mathrm{~nm} ; l=1.0 \mathrm{~cm}\right)$

\begin{tabular}{cccccc}
\hline $\begin{array}{c}\text { Foreign } \\
\text { ion }\end{array}$ & $\begin{array}{c}\text { Tolerance limit } \\
\mathbf{C}_{\text {ion }}: \mathbf{C}_{\text {Ir(IV) }}\end{array}$ & $\begin{array}{c}\text { Foreign } \\
\text { ion }\end{array}$ & $\begin{array}{c}\text { Tolerance limit } \\
\mathbf{C}_{\text {ion }}: \mathbf{C}_{\mathbf{I r}(\mathrm{IV})}\end{array}$ & $\begin{array}{c}\text { Foreign } \\
\text { ion }\end{array}$ & $\begin{array}{c}\text { Tolerance limit } \\
\mathbf{C}_{\text {ion }}: \mathbf{C}_{\mathbf{I r}(\mathrm{IV})}\end{array}$ \\
\hline $\mathrm{Pd}(\mathrm{II})$ & 0.1 & $\mathrm{Ni}(\mathrm{II})$ & 150 & $\mathrm{Ca}(\mathrm{II}), \mathrm{Mg}(\mathrm{II})$ & $>200$ \\
$\mathrm{Pt}(\mathrm{IV})$ & 0.25 & $\mathrm{Fe}(\mathrm{III})$ & 15 & $\mathrm{C}_{2} \mathrm{O}_{4}{ }^{2-^{*}}$ & 100 \\
$\mathrm{Rh}(\mathrm{III})$ & 0.1 & $\mathrm{Cd}(\mathrm{II})^{*}$ & 75 & $\mathrm{~F}^{-*}$ & 100 \\
$\mathrm{Ru}(\mathrm{IV})$ & 0.25 & $\mathrm{~Pb}(\mathrm{II})^{*}$ & 75 & $\mathrm{EDTA}^{*}$ & 100 \\
$\mathrm{~Tb}(\mathrm{III})$ & 100 & $\mathrm{Mn}(\mathrm{II})^{*}$ & 100 & $\mathrm{Sal}^{-*}$ & 100 \\
$\mathrm{Gd}(\mathrm{III})$ & 75 & $\mathrm{Zn}(\mathrm{II})$ & 75 & $\mathrm{Citr}^{3-*}$ & 100 \\
$\mathrm{Cu}(\mathrm{II})$ & 50 & $\mathrm{Al}(\mathrm{III})$ & 8 & $\mathrm{Tart}^{2-*}$ & 100 \\
$\mathrm{Co}(\mathrm{II})$ & 30 & $\mathrm{Ba}(\mathrm{II})$ & 75 & $\mathrm{PO}_{4}{ }^{3-*}$ & 100 \\
\hline
\end{tabular}

*These ions decrease the absorbance value by $\pm 5 \%$, and the others all increase.

Table 2. Determination of Iridium(IV) in synthetic mixtures, $\mathrm{n}=3 ; \mathrm{P}=0.95$

\begin{tabular}{lccr}
\hline Composition of synthetic mixture & $\begin{array}{c}\text { Added } \\
\mathbf{I r}(\mathbf{I V}), \boldsymbol{\mu g}\end{array}$ & $\begin{array}{c}\text { Found } \mathbf{I r}(\mathrm{IV}), \\
\overline{\boldsymbol{x}} \pm \frac{\boldsymbol{s} \times \boldsymbol{t}_{\boldsymbol{\alpha}}}{\sqrt{\boldsymbol{n}}}, \boldsymbol{\mu g}\end{array}$ & $\mathbf{R S D , \%}$ \\
\hline $12.6 \mu \mathrm{g} \mathrm{Ru}(\mathrm{IV}), 0.7 \mathrm{mg} \mathrm{Co}(\mathrm{II})$ & 96 & $98 \pm 5$ & 2.0 \\
$3.3 \mu \mathrm{g} \mathrm{Pd}(\mathrm{II}), 2.8 \mathrm{mg} \mathrm{Ni}(\mathrm{II}), 9.7 \mathrm{mg} \mathrm{Pb}(\mathrm{II})$ & 96 & $101 \pm 7$ & 2.8 \\
$24.4 \mu \mathrm{gt}(\mathrm{IV}), 3.4 \mathrm{mg} \mathrm{Mn}(\mathrm{II})$ & 96 & $100 \pm 8$ & 3.2 \\
\hline
\end{tabular}


Table 3. Results of the determination of $\operatorname{Ir}(\mathrm{IV})$ in alloys, $\mathrm{n}=3, \mathrm{P}=0,95$

\begin{tabular}{|c|c|c|c|c|c|}
\hline Alloy & $\omega_{I r}^{c a l c}$ & $\begin{array}{l}\text { Spectrophotometry } \\
\bar{\omega}_{I r}^{p r} \pm \frac{S \times t_{\alpha}}{\sqrt{n}}, \%\end{array}$ & RSD, \% & $\begin{array}{l}\text { Voltammetry } \\
\bar{\omega}_{I r}^{p r} \pm \frac{S \times t_{\alpha}}{\sqrt{n}}, \%\end{array}$ & RSD, \% \\
\hline $\mathrm{Gd}_{2} \mathrm{Ir}_{3} \mathrm{Al}_{9}$ & 50.9 & $51.5 \pm 1.8$ & 1.4 & $51.2 \pm 1.4$ & 1.1 \\
\hline $\mathrm{Tb}_{2} \mathrm{Ir}_{3} \mathrm{Al}_{9}$ & 50.7 & $51.0 \pm 1.5$ & 1.2 & $50.8 \pm 1.6$ & 1.3 \\
\hline
\end{tabular}

added amounts of $\operatorname{Ir}(\mathrm{IV})$. The calculated values of the relative standard deviation and the absence of a significant systematic error indicate a good reproducibility and accuracy of this spectrophotometric method.

\section{Analysis of Ir(IV) in the alloys}

The results of Iridium determination in the alloys are given in Table 3. The data obtained by the spectrophotometric method were compared with $\operatorname{Ir}(\mathrm{IV})$ contents determined by the voltammetric method. As seen, the results of both methods are agreemented. The results in Table 3 show that the relative error and relative standard deviation do not exceed $1.5 \%$.

\section{Conclusions}

The results of this research indicate that the developed spectrophotometric method based on the complexation of $\operatorname{Ir}(\mathrm{IV})$ with the new azolidone derivative (5-[2-(4-hydroxyphenyl)-hydrazineylidene]-4-iminothiazolidin-2-one) can be successfully used for the determination of iridium(IV) in different samples. This method is simple, sensitive, selective towards many ions, reproducible, and rapid because it does not require heating or separation from a large number of foreign ions (such as REE, $\mathrm{Cu}(\mathrm{II}), \mathrm{Ni}(\mathrm{II}), \mathrm{Mn}(\mathrm{II}), \mathrm{Zn}(\mathrm{II}), \mathrm{Cd}(\mathrm{II})$, et al.), which are associated with $\operatorname{Ir}(\mathrm{IV})$ in its objects. The time needed for analysis about $30 \mathrm{~min}$, which makes this method much faster than other spectrophotometric methods for determining Iridium, which are described in the literature.

\section{References}

1. Ya. A. Zolotov, G. M. Varshal, V. M. Ivanov, Analiticheskaya Khimiya Metallov Platinovoi Gruppy, Editorial URSS, Moscow, Russia, 2003, p. 592.

2. S. I. Ginzburg, N. A. Yezerskaya, I. V. Prokof'eva, N. V. Fedorenko, V. I. Shlenskaya, N. K. Belsky, Analiticheskaya Khimiya Platinovykh Metallov, Nauka, Moscow, Russia, 1972, p. 613.

3. R. F. Gur'eva, S.B. Savvin, Zh. Anal. Khim. 2002, 57, 980 -996. DOI:10.1023/A:1020917221896

4. R. F. Gur'eva, S. B. Savvin, Usp. Khim. 1998, 67, 236-251.

DOI:10.1070/RC1998v067n03ABEH000375

5. S. B. Savvin, R. F. Gur'eva, Talanta 1987, 34, 87-101.

\section{DOI:10.1016/0039-9140(87)80012-7}

6. E. Tang, G. Yang, J. Yin, Spectrochim. Acta, Part A. 2003, 59, 651-656. DOI:10.1016/S1386-1425(02)00209-3

7. L. Lozynska, O. Tymoshuk, Chem. Chem. Technol. 2013, 7, 391-395. DOI:10.23939/chcht07.04.391

8. L. Lozynska, O. Tymoshuk, In: O. L. Berezko, The Interaction of 5-hydroxyimino-4-imino-1,3-thiazolidin-2-one with Platinum(IV) Ions, $3^{\text {rd }}$ International Conference of Young Scientists CCT-13, Lviv, Ukraine, 2013, 166.

9. L. V. Lozynska, O. S. Tymoshuk, T. I. Chaban, Methods Objects Chem. Anal. 2014, 9, 50-54.

DOI:10.17721/moca.2014.50-54

10. L. V. Lozynska, O. S. Tymoshuk, Issues Chem. Chem. Technol., 2014, 1, 80-85.

11. L. V. Lozyns'ka, O. S. Tymoshuk, T. Ya. Vrublevs'ka, Materials Science 2015, 6, 870-876. DOI:10.1007/s11003-015-9795-y

12. L. Lozynska, O. Tymoshuk, T. Chaban, Acta Chim Slov. 2015, 62, 159-167. DOI:10.17344/acsi.2014.866

13. A. Tupys, O. Tymoshuk, P. Rydchuk, Chem. Chem. Technol. 2016, 10, 19-25. DOI:10.23939/chcht10.01.019

14. A. Tupys, J. Kalembkiewicz, Y. Bazel, L. Zapala, M. Dranka, Y. Ostapiuk, O. Tymoshuk, E. Woźnicka, J. Mol. Struct. 2017, 1127, 722-733. DOI:10.1016/j.molstruc.2016.07.119

15. A. Tupys, J. Kalembkiewicz, Y. Ostapiuk, V. Matiichuk, O. Tymoshuk, E. Woźnicka, L. Byczyński, J. Therm. Anal. Calorim. 2017, 127, 2233-2242. DOI:10.1007/s10973-016-5784-0

16. M. Fizer, V. Sidey, A. Tupys, Y. Ostapiuk, O. Tymoshuk, Y. Bazel, J. Mol. Struct. 2017, 1149, 669-682.

DOI:10.1016/j.molstruc.2017.08.037

17. Y. Bazel, A. Tupys, Y. Ostapiuk, O. Tymoshuk, V. Matiychuk, J. Mol. Liq., 2017, 242, 471-477.

DOI:10.1016/j.molliq.2017.07.047

18. Y. Bazel, A. Tupys, Y. Ostapiuk, O. Tymoshuk, J. Imricha, J. Šandrejová, RSC Adv., 2018, 8, 15940-15950.

DOI:10.1039/C8RA02039F

19. O. Tymoshuk, L. Oleksiv, L. Khvalbota, T. Chaban, I. Patsay, Acta Chim Slov. 2019, 66, 62-69.

DOI:10.17344/acsi.2018.4448

20. P. V. Rydchuk, O. S. Tymoshuk, L. V. Oleksiv, T. I. Chaban, V. S. Matiychuk, Methods Objects Chem. Anal. 2019, 14, 130139. DOI:10.17721/moca.2019.130-139

21. O. S. Tymoshuk, O. S. Fedyshyn, L. V. Oleksiv, P. V. Rydchuk, I. O. Patsai, Materials Science 2019, 55, 455-459.

DOI:10.1007/s11003-019-00325-9

22. V. Drušković, V. Vojković, S. Miko, Talanta 2004, 62, 489-495. DOI:10.1016/j.talanta.2003.08.031

23. L. Zhang, N. Li, P. Fan, X. Chu, S. An, J. Zhang, X.Wang, Hy- 
drometallurgy 2012, 127-128, 8-15.

DOI:10.1016/j.hydromet.2012.06.012

24. V. Drušković, V. Vojković, Croat. Chem. Acta 2003, 76, 49-54.

25. A. S. Amin, I. A. Zaafarany, Anal. Chem. Res. 2015, 3, 77-81. DOI: $10.1016 /$ j.ancr.2014.10.001

26. M. A. Taher, S. Puri, R. K. Bansal, B. K. Puri, Talanta 1997, 45, 411-416. DOI:10.1016/S0039-9140(97)00149-5

27. S. Kuchekar, S. Bhumkar, H. Aher, S. H. Han, J. Mater. Environ. Sci. 2019, 10, 1200-1213. DOI:10.20959/wjpps20174-8960

28. I. Patsay, P. Rydchuk, O. Tymoshuk, Visnyk of the Lviv Univer- sity. Series Chemistry 2017, 58, 219-224.

29. N. E. Ezerskaya, I. N. Kiseleva, Zh. Anal. Khim. 2001, 967970, 855-858. DOI:10.1023/A:1016768614942

30. Yu.Yu. Lur'e, Spravochnik po analiticheskoi khimii, Khimiya, Moscow, Russia, 1971, p. 456.

31. Yu. Lutsyshyn, Ya. Tokaychuk, P. Demchenko, R. Gladyshevskii, Visnyk of the Lviv University. Series Chemistry 2010, $51,52-59$.

32. L. Khvalbota, O. Tymoshuk, V. Matiychuk, Visnyk of the Lviv University. Series Chemistry 2016, 57, 219-225.

\section{Povzetek}

V prispevku je predstavljen nov derivat azolidona - 5-[2-(4-hidroksifenil)hidrazineiliden]-4-iminotiazolidin-2-on (HPIT) in rezultati njegove interakcije $\mathrm{z}$ ioni iridija(IV). $\operatorname{Ir}(\mathrm{IV})$ ion $\mathrm{s}$ tem reagentom pri $\mathrm{pH}=5,0$ brez segrevanja tvori stabilen kompleks $\left(\lambda_{\max }=328 \mathrm{~nm}\right)$. Stehiometrično razmerje $\operatorname{Ir}(\mathrm{IV})$ in reagenta v kompleksu je 1:1. Molarna absorptivnost in Sandellova občutljivost sta $5,57 \times 10^{3} \mathrm{~L} \mathrm{~mol}^{-1} \mathrm{~cm}^{-1}$ in $0,034 \mu \mathrm{g} \mathrm{cm}{ }^{-2}$. Kalibracijska krivulja je linearna v območ-

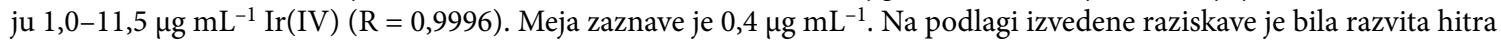
in enostavna spektrofotometrična metoda za določanje $\operatorname{Ir}(\mathrm{IV}) \mathrm{z}$ uporabo 5-[2-(4-hidroksifenil) hidrazineilidena]-4-iminotiazolidin-2-ona kot kromofornega reagenta. Ir(IV) je bil določen v različnih sintetičnih mešanicah in zlitinah.

Except when otherwise noted, articles in this journal are published under the terms and conditions of the Creative Commons Attribution 4.0 International License 